\title{
DESKRIPSI PENGETAHUAN DAN PEMAHAMAN MAHASISWA AKADEMI KEBIDANAN TAHIRAH AL BAETI TENTANG ANEMIA IBU HAMIL
}

\author{
Mudyawati Kamaruddin $^{1 *}$, Nurhayani ${ }^{1}$, Idar Karlina ${ }^{1}$ \\ ${ }^{1}$ Program Studi Kebidanan, Akademi Kebidanan Tahirah Al Baeti, Bulukumba, Sulawesi Selatan, \\ Indonesia
}

*Corresponding author: Telp: +628111520603, email: mudya07@ gmail.com

\begin{abstract}
ABSTRAK
Anemia adalah suatu keadaan dimana tubuh memiliki jumlah sel darah merah yang terlalu sedikit, yang mana jumlah sel darah merah itu ditentukan dengan kadar hemoglobin. Anemia pada kehamilan adalah suatu keadaan berkurangnya sel darah merah dalam sirkulasi darah atau massa hemoglobin, dimana kadar $\mathrm{Hb}$ di bawah 11 gr\% pada trimestrer I dan II atau kadar Hb kurang dari 10,5 gr\% pada trimester III. Mahasiswa akademi kebidanan penting mempunyai pengetahuan dan pemahaman tentang anemia pada ibu hamil yang adekuat sebagai bekal mereka untuk berinteraksi dengan komunitas dan bertemu klien. Tujuan penelitian andalah mendeskripsikan pengetahuan dan pemahaman mahasiswa Akbid Tahira Al Baeti tentang anemia ibu hamil. Metode. Jenis penelitian yang digunakan adalah jenis penelitian deskriptif dengan menggunakan sampel mahasiswa tingkat I dan II AKBID Tahirah Al Baeti Bulukumba sebanyak 42 responden, instrumen penelitian yang digunakan adalah kuesioner. Berdasarkan data kuesioner diperoleh bahwa pengetahuan mahasiswa Akademi Kebidanan Tahirah Al Baeti Bulukumba tentang anemia pada ibu hamil berada pada tingkat berpengetahuan baik untuk mahasiswa tingkat II (100\%) dibandingkan dengan mahasiswa tingkat I (50\%). Sedangkan tingkat pemahaman mahasiswa Akademi Kebidanan Tahirah al Baeti Bulukumba tentang anemia pada ibu hamil adalah $95.5 \%$ untuk mahasiswa tingkat II, dan 50\% untuk mahasiswa tingkat I. Walau secara keseluruhan mahasiswa Akbid Tahirah Al Baeti BUlukumba baik tingkat I maupun II mempunyai pengetahuan dan pemahaman yang cukup baik. Hal ini disebabkan tingkat dan lama proses belajar mengajar mendukung tingkatan pengetahuan dan pemahaman.
\end{abstract}

Kata kunci : Pemahaman, Pengetahuan, Anemia Ibu Hamil, Mahasiswa

\begin{abstract}
Anemia is a condition in which the body has a small number of red blood cells, which are determined by hemoglobin levels. Anemia in pregnancy is a state of reduced red blood cells in the blood circulation or hemoglobin mass, where Hb levels below $11 \mathrm{gr} \%$ in trimestrers I and II or Hb levels less than $10.5 \mathrm{gr} \%$ in trimester III. important for Midwifery Academy Students in particular to have adequate knowledge and understanding of anemia in pregnant women as their provision to interact with the community and meet clients. This study aims to describe the knowledge and understanding of Tahira Al Baeti Midwifery Academy students about anemia in pregnant women. This research uses descriptive research by participating in the Tahira Al Baeti midwifery Academy students level I and II, amounting to 42 students. The research instrument used was a questionnaire. Based on the questionnaire data it was found that the knowledge of the Tahirah al Baeti Midwifery Academy students about anemia in pregnant women was at agood level of knowledge for the second-level students (100\%) compared to the first-level $(50 \%)$. While the level of understanding of Tahirah Al Baeti Midwifery Academy students about anemia in pregnant women was 95.5\% for the second level students, and $50 \%$ for first-degree students. This is due to the level and length of teaching and learning process supporting the level of knowledge and understanding. Knowledge and understanding which possessed by Tahirah Al Baeti Midwifery Academy students about anemia in pregnant women is pretty good category.
\end{abstract}

Keywords: Understanding, Knowledge, Students, Anemia of Pregnant Women 


\section{PENDAHULUAN}

Anemia adalah suatu kondisi dimana jumlah dan ukuran sel darah merah atau konsentrasi haemoglobin $(\mathrm{Hb})$ dibawah nilai batas normal, dengan kata lain jumlah sel darah merah (eritrosit) yang terlalu sedikit, dimana sel darah merah mengandung $\mathrm{Hb}$ yang berfungsi untuk membawa oksigen ke seluruh jaringan tubuh. Akibatnya dengan kondisi anemia dapat mengganggu kapasitas darah untuk mengangkut oksigen keseluruhan tubuh. Anemia merupakan indikator untuk gizi buruk dan kesehatan yang buruk (Properawati, 2013). Anemia rentang dialami pada semua siklus kehidupan, yaitu balita, dewasa, ibu hamil, dan ibu menyusui (Kusmiran, 2013). Penyebab anemia diantaranya adalah kehilangan darah yang berat seperti yang terjadi pada saat menstruasi dan infeksi parasit, kondisi seperti malaria dan HIV yang menurunkan konsentrasi $\mathrm{Hb}$ darah, dan terutama pada pertumbuhan dan kehamilan bila kebutuhan zat besi lebih tinggi juga merupakan faktor risiko anemia. Pada ibu hamil anemia meningkatkan risiko kematian ibu dan anak dan memiliki konsekuensi negatif pada perkembangan kongnitif dan fisik pada anak serta produktivitas kerja (Obay, Odongo dan Wanyama, 2016).

Data World Health Organization (WHO) 2010, sebanyak 40\% kematian ibu di negara berkembang berkaitan dengan anemia dalam kehamilan. Kebanyakan anemia dalam kehamilan disebabkan oleh defisiensi besi dan perdarahan akut, bahkan jarak keduanya saling berinteraksi (Martini dan Oktaviani, 2017). Masih menurut data WHO, diperkirakan bahwa 35-37\% ibu hamil di negara berkembang dan $18 \%$ ibu hamil di negara maju mengalami anemia. Namun, banyak diantara mereka yang telah menderita anemia pada saat konsepsi, dengan perkiraan prevalensi sebesar $43 \%$ pada perempuan yang tidak hamil di negara berkembang dan $12 \%$ di negara yang lebih maju (Fadhila, 2014).Menurut data hasil
Riset Kesehatan Dasar (Riskesdas) tahun 2013, prevalensi anemia di Indonesia yaitu $21,7 \%$ dengan penderita anemia berumur 514 tahun sebesar $26,4 \%$ dan $18,4 \%$ penderita berumur 15-24 tahun (Kemenkes RI,2014). Data Survei kesehatan rumah tangga (SKRT) tahun 2012 menyatakan bahwa prevalensi anemia pada balita sebesar 40,5\%, ibu hamil sebesar 50,5\%, ibu nifas sebesar 39,5\%. Wanita mempunyai resiko anemia paling tinggi terutama pada remaja putri (Kemenkes RI, 2015). Pemberian tablet Fe (Ferrum) di Indonesia pada tahun 2012 sebesar 85\% presentase mengalami peningkatan dibandingkan pada tahun 2011 yang sebesar 83,3\%. Meskipun pemerintah sudah melakukan program penanggulangan anemia pada ibu hamil yaitu dengan memberikan 90 tablet Fe kepada ibu hamil selama periode kehamilan dengam tujuan menurunkan angka anemia ibu hamil, akan tetapi kejadian anemia masih tinggi (Kemenkes RI., 2015).

Data yang diperoleh dari Dinas Kesehatan Provinsi Sulawesi Selatan, pada tahun 2015 jumlah kasus anemia adalah 22.620 orang $(2,96 \%)$ dari 765.000 kehamilan. Dengan klasifikasi sebagai berikut: anemia ringan sebanyak 8.900 orang (39.35\%), anemia sedang adalah 9.690 orang $(42.84 \%)$, dan anemia berat sebanyak 4.030 orang $(17,82 \%)$ (Profil Dinkes Sulawesi Selatan, 2015). Sedangkan Dinas Kesehatan Kabupaten Bulukumba tahun 2015 mendata jumlah kasus anemia adalah sebanyak 1.667 orang, dan tahun 2017 sebanyak 6.085 ibu hamil yang menderita anemia (Profil Dinkes Bulukumba 2015 dan 2017).

Berdasarkan data di atas bahwa penderita anemia khususnya pada ibu hamil masih sangat tinggi, sehingga memberikan peluang bagi penggiat kesehatan untuk membantu penanggulangan anemia. Hal ini dapat dimulai dari mahasiswa khususnya akademi kebidanan yang akan terjun langsung berhadapan dengan ibu-ibu hamil. 
Untuk itu, pengetahuan dan pemahaman akan anemia sudah menjadi kewajiban bagi mahasiswa kebidanan sebelum terjun ke lapangan, dan peneliti tertarik untuk mengetahui bagaimana pengetahuan dan pemahaman mahasiswa kebidanan tentang anemia ibu hamil. Sehingga pada penelitian ini dilakukan di Akademi Kebidanan Tahirah Al Baeti Bulukumba.

\section{METODOLOGI}

\section{Lokasi, Sampel dan Jenis Penelitian}

Penelitian berlokasi di Akademi Kebidanan Tahirah Al Baeti Bulukumba dengan responden adalah mahasiswa tingkat I dengan jumlah 22 mahasiswa dan tingkat II dengan jumlah 20 mahasiswa yang memenuhi persyaratan sebagai responden dalam penelitian. Jenis penelitian ini menggunakan penelitian deskriptif untuk mengetahui gambaran pengetahuan dan pemahaman mahasiswa Akademi Kebidanan Tahirah Al Baeti tentang anemia ibu hamil yang menggunakan data primer dimana semua data diperoleh dari hasil kuesioner yang telah diisi oleh responden.

\section{Metode Pengumpulan Data}

Metode pengumpulan data dengan menggunakan data primer dimana peneliti melakukan pendataan langsung tentang identitas mahasiswa yang dijadikan responden penelitian. Identitas mahasiswa meliputi nama, tempat tanggal lahir, usia dan alamat dengan cara wawancara. Kemudian setiap responden diberikan lembar kuesioner sesuai dengan petunjuk yang berlaku.

\section{HASIL DAN PEMBAHASAN}

HASIL

a. Gambaran pengetahuan mahasiswa tentang anemia ibu hamil

Distribusi

pengetahuan

mahasiswa tingkat I dan II Akademi

Kebidanan Tahirah Al Baeti

Bulukumba tentang anemia pada ibu hamil disajikan pada table 4.1 di bawah ini :

Tabel 4.1 Distribusi frekuensi responden berdasarkan pengetahuan responden tentang anemia pada ibu hamil di Akbid Tahirah Al Baeti (AKTABE)

\begin{tabular}{cccccc}
\hline \multirow{2}{*}{ Pengetahuan } & \multicolumn{3}{c}{ Tingkatan } & \multirow{2}{*}{ Total } \\
\cline { 2 - 5 } & Baik & Cukup & Kurang & \\
\hline Mahasiswa Tingkat I & 5 & 10 & 5 & 20 \\
\hline $\begin{array}{c}\text { Mahasiswa Tingkat } \\
\text { II }\end{array}$ & 22 & 0 & 0 & 22 \\
\hline Total & 27 & 10 & 5 & $\mathbf{4 2}$
\end{tabular}

Sumber: Data primer pengetahuan Mahasiswa tingkat I\&II AKTABE (Karlina I., 2019)

Dari table 4.1 menunjukan bahwa dari 42 responden yang diteliti menunjukkan pengetahuan yang cukup tentang anemia ibu hamil didominasi oleh responden yang berstatus mahasiswa tingkat I yaitu $50 \%$ dari total responden. Sedangkan pengetahuan tentang anemia ibu hamil berada ditingkat $100 \%$ oleh mahasiswa tingkat II.

\section{b. Gambaran pemahaman mahasiswa tentang anemia ibu hamil} Distribusi pemahaman mahasiswa tingkat I dan II Akademi Kebidanan Tahirah Al Baeti Bulukumba tentang anemia pada ibu hamil disajikan pada table 4.1 di bawah ini: 
Tabel 4.2 Distribusi frekuensi responden berdasarkan pemahaman responden tentang anemia pada ibu hamil di Akbid Tahirah Al Baeti (AKTABE)

\begin{tabular}{ccc|c|c}
\hline \multirow{2}{*}{ Pemahaman } & \multicolumn{3}{c}{ Tingkatan } & Total \\
\cline { 2 - 4 } & Baik & Cukup & Kurang & \\
\hline $\begin{array}{c}\text { Mahasiswa Tingkat } \\
\text { I }\end{array}$ & 4 & 10 & 6 & 20 \\
\hline $\begin{array}{c}\text { Mahasiswa Tingkat } \\
\text { II }\end{array}$ & 21 & 1 & 0 & 22 \\
\hline Total & 25 & 11 & 6 & $\mathbf{4 2}$
\end{tabular}

Sumber: Data primer pengetahuan Mahasiswa tingkat I\&II AKTABE (Karlina I., 2019)

Dari table 4.2 di atas, hasil penelitian menunjukkan bahwa pemahaman responden dari mahasiswa tingkat I tentang anemia ibu hamil dengan tingkatan pemahaman yang baik $20 \%$, pemahaman yang cukup adalah $50 \%$ dan kurang $30 \%$. Adapun responden dari mahasiswa tingkat II, pemahaman tentang anemia ibu hamil dengan tingkatan baik adalah $95.5 \%$ dan cukup hanya $4.5 \%$

\section{PEMBAHASAN}

Pengetahuan merupakan pengindraan manusia terhadap suatu obyek tertentu. Proses pengindraan terjadi melalui pancaindra manusia, yakni indra penglihatan, pendengaran, penciuman, rasa dan melalui kulit. Pengetahuan atau kognitif merupakan domain yang sangat penting untuk terbentuknya tindakan seseorang (Notoatmodjo, 2014). Hasil penelitian terhadap pengetahuan mahasiswa Akademi Kebidanan Tahirah Al Baeti tentang anemia ibu hamiL, dari 42 responden terdapat $64,3 \%$ mahasiswa yang berpengetahuan baik, dan sebanyak $23,8 \%$ yang berpengetahuan cukup tentang anemia ibu hamil, jumlah mahasiswa yang mempunyai pengetahuan baik ini merupakan jumlah yang mayoritas. Hal ini tidak menutup kemungkinan hampir semua mahasiswa AKBID Tahirah Al Baeti Bulukumba sudah mengetahui banyak tentang anemia pada ibu hamil, dimana mata kuliah tentang anemia adalah mata kuliah inti dalam kurikulum program D-III
AKBID. Mahasiswa kesehatan khususnya Akademi Kebidanan, mempelajari tentang anemia terspesifik pada ibu hamil sebagai ilmu wajib yang diketahui sebelum mengambil mata kuliah lanjutan. Selain itu, hampir semua mahasiswa AKBID mempunyai dasar ilmu eksakta atau kesehatan sebelumnya. Adapun jika ada mahasiswa yang mempunyai pengetahuan kurang tentang anemia pada ibu hamil, kemungkinan disebabkan dasar keilmuan yang dimiliki mahasiswa adalah ilmu sosial yang tidak pernah mempelajari tentang anemia apalagi pada ibu hamil sebelumnya. Hal ini ditunjukkan dengan hasil yang diperoleh pada distribusi pengetahuan mahasiswa tingkat I dan II AKBID Tahirah Al Baeti Bulukumba dari total 42 mahasiswa yang ikut sebagai responden hanya $11,9 \%$ yang mempunyai pengetahuan kurang. Dari hasil analisis responden yang berpengetahuan kurang diperoleh dari mahasiswa tingkat I yaitu $25 \%$ dan hal ini mungkin disebabkan masih kurang pengetahuan tentang beberapa obat-obatan tentang anemia yang ditunjukkan pada lembar kuesioner. Sedangkan pada mahasiswa tingkat II menunjukkan mayoritas mahasiswa berpengetahuan baik yaitu $100 \%$. Pengetahuan memiliki beberapa tingkatan salah satunya adalah tahu yang merupakan keberhasilan mengumpulkan keterangan apa adanya. Termasuk dalam kategori ini adalah kemampuan mengenali atau mengingat kembali hal-hal atau keterangan 
yang pernah berhasil dihimpun atau dikenali (Notoatmodjo, 2014).

Menurut Sudjana Nana (2013), pemahaman adalah hasil belajar dimana peserta didik dapat menjelaskan dengan susunan kalimatnya sendiri atas apa yang dibacanya atau didengarnya, memberi contoh lain dari yang telah dicontohkan dan menggunakan petunjuk penerapan pada kasus lain. Sedangkan menurut Sudaryono (2012), Pemahaman adalah kemampuan seseorang untuk menangkap makna dan arti dari bahasa yang dipelajari, yang dinyatakan dengan menguraikan isi pokok dari suatu bacaan atau mengubah data yang disajikan dalam bentuk tertentu ke bentuk yang lain. Penelitian yang dilakukan terhadap pemahaman mahasiswa tingkat I dan II AKBID Tahirah Al Baeti Bulukumba juga sejalan dengan pengetahuan mahasiswa tersebut, dimana hasil yang diperoleh mayoritas mahasiswa tingkat II mempunyai pemahaman yang baik tentang anemia pada ibu hamil yaitu $95,5 \%$ baik dan sebesar $4,5 \%$ berpemahaman cukup.

\section{KESIMPULAN}

Berdasarkan hasil penelitian terhadap 42 responden yang dilakukan pada mahasiswa tingkat I dan II di Akademi Kebidanan Tahirah Al Baeti Bulukumba tentang deskripsi pengetahuan dan pemahaman mahasiswa tentang anemia pada ibu hamil, dapat disimpulkan bahwa hampir semua mahasiswa mempunyai pengetahuan dan pemahaman yang cukup baik tentang anemia pada ibu hamil.

\section{DAFTAR PUSTAKA}

1. Fadilla. 2014. Buku Ajaran Kebidanan Yogyakarta: Nuha Medika.

2. Kamus Besar Bahasa Indonesia. [Online]. Tersedia di KKBI digilib.unila.ac.id/881/11/3.\%20BAB\% 20III.pdf. Diakses 24 november 2018.
3. Kementrian Kesehatan RI. (2015). Buku Ajaran Kesehatan Ibu dan Anak, Jakarta: Pusat Pendidikan dan Pelatihan Tenaga kesehatan. (di akses pada tahun 2018).

4. Kusmiran, E, (2013). Kesehatan Reproduksi Remaja Dan Wanita, Salemba Medika, Jakarta. Diakses tanggal 23 November 2018

5. Martini. S dan Oktaviani.D. 2017. Hubungan tingkat pengetahuan ibu hamil tentang tablet $\mathrm{Fe}$ dengan Kepatuhan Ibu Hamil mengomsumsi Tablet Fe. Jurnal Kesehatan Ibu dan Anak Akademi Kebidanan An-Nur. Vol 2 No 1. Hal 22-29. ( diakses pada tahun 2018)

6. Notoatmojodjo,S. 2012. Metodologi

Penelitian Kesehatan.jakarta:Rineka Cipta.

7. Notoatmodjo, S. 2014. Ilmu Perilaku Kesehatan. Jakarta : Rineka Cipta.

8. Obay, Gerald., Ondongo, pancras., \& Wanyama, Ronald. (2016). Prevalence of Anaemia and Associated Risk Factors among Pregnant Women Attending ANC in Gulu and Hoima Regional Hospital in Uganda: A Cross Sectional Study. BMC Journal Pregnancy and childbirth. Trusted 2016.

9. Properawati, A. (2013). Anemia dan anemia kehamilan. Yogyakarta: Nuha Medika. (diakses pada tahun 2018)

10. Profil Dinas Kesehatan Sulawesi Selatan. Dinkes Prov. Makassar. Diakses 2015.

11. Profil Dinas Kesehatan Kabupaten Bulukumba. Dinkes Kab. Bulukumba. Diakses 2015 \& 2017

12. Sudaryono. 2012. Dasar-Dasar Evaluasi Pembelajaran. Yogyakarta: Graha Ilmu

13. Sudjana, Nana. 2013. Dasar-Dasar Proses Belajar Mengajar. Bandung: Sinar Baru Algensindo. 